\title{
Erythema gyratum repens: a paraneoplastic eruption
}

\author{
May MeiQi Liau, Valencia Long, Shiyao Sam Yang
}

National University Hospital, Singapore, Singapore

\section{Correspondence to}

May MeiQi Liau,

maylmq@gmail.com

Accepted 21 February 2016

\section{DESCRIPTION}

A 77-year-old woman was evaluated for a 3-week history of rash on her lower limbs. The eruption began as a small erythematous macule, and gradually enlarged with time. The patient had atrial fibrillation on anticoagulation therapy. On physical examination, there were annular, erythematous lesions that appeared in concentric, raised bands lined by trailing edge of scales over the lateral aspect of her right thigh (figure 1). A clinical diagnosis of erythema gyratum repens was made. The remainder of her

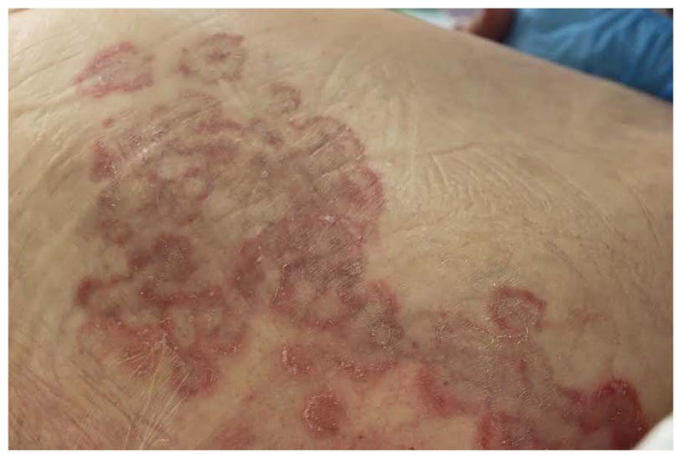

Figure 1 Annular, erythematous rash lined by trailing edge of scale, characteristic of erythema gyratum repens in this patient with cholangiocarcinoma.

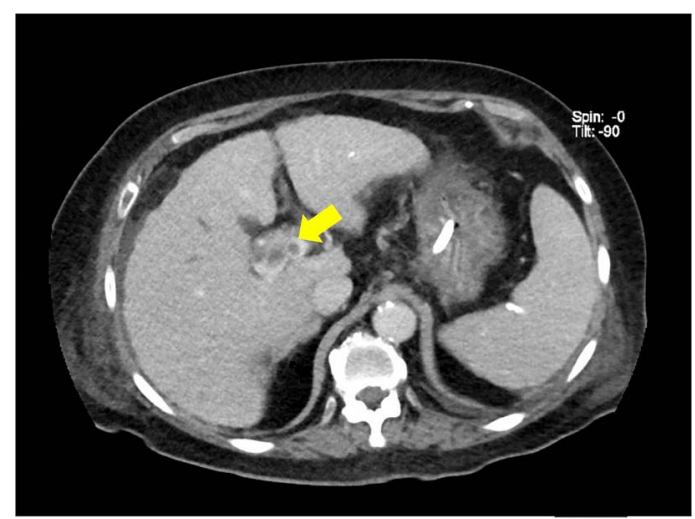

Figure 2 CT abdomen showing an $18 \times 17 \mathrm{~mm}$ hypodense lesion in the liver hilar region (yellow arrow), suggestive of cholangiocarcinoma. examination was remarkable for scleral icterus, abdominal distension with clinical evidence of ascites and inguinal lymphadenopathy. A CT scan revealed a hypodense lesion measuring $18 \times 17 \mathrm{~mm}$ in the liver hilar region, suggestive of cholangiocarcinoma, with infiltration of adjacent segment 8 . There was also associated bile duct dilation and thrombosis of the portal vein (figure 2). The patient and her family opted for conservative palliative management of her intra-abdominal malignancy. A trial of topical corticosteroids was initiated. She died 2 months after diagnosis; the rash had not resolved.

\section{Learning points}

- Erythema gyratum repens (EGR), first described by Gammel, ${ }^{1}$ in 1952, is a rare paraneoplastic syndrome typically associated with an underlying malignancy. The most common include lung carcinoma, oesophageal carcinoma and breast carcinoma. ${ }^{2}$

- It often precedes the diagnosis of cancer by several months. Hence, recognition of this rash can allow for urgent referral for diagnostic evaluation.

- Treatment of EGR is difficult and aimed at treatment of the underlying malignancy. Steroids (systemic and topical), vitamin A and azathioprine are frequently ineffective.

Contributors VL contributed to the content and organisation of information. MML contributed to the retrieval of data, content and organisation of information. SY contributed to content and organisation of information.

Competing interests None declared.

Patient consent Obtained.

Provenance and peer review Not commissioned; externally peer reviewed.

\section{REFERENCES}

1 Gammel JA. Erythema gyratum repens. Arch Dermatol Syph 1952;66:494-505.

2 Stone SP, Buescher LS. Life-threatening paraneoplastic cutaneous syndromes. Clin Dermatol 2005;23:301-6. 


\section{Images in...}

Copyright 2016 BMJ Publishing Group. All rights reserved. For permission to reuse any of this content visit http://group.bmj.com/group/rights-licensing/permissions.

BMJ Case Report Fellows may re-use this article for personal use and teaching without any further permission.

Become a Fellow of BMJ Case Reports today and you can:

- Submit as many cases as you like

- Enjoy fast sympathetic peer review and rapid publication of accepted articles

- Access all the published articles

- Re-use any of the published material for personal use and teaching without further permission

For information on Institutional Fellowships contact consortiasales@bmjgroup.com

Visit casereports.bmj.com for more articles like this and to become a Fellow 